\title{
Further Studies on Cation Clock Reactions in Glycosylation: Observation of a Configuration Specific Intramolecular Sulfenyl Transfer and Isolation and Characterization of a Tricyclic Acetal
}

Min Huang, ${ }^{\mathrm{a}, \dagger}$ Takayuki Furukawa, ${ }^{\mathrm{b}, \star}$ Pascal Retailleau, ${ }^{\mathrm{a}}$ David Crich, ${ }^{\mathrm{b}, *}$ and Luis Bohée ${ }^{\mathrm{a}, *}$

a) Institut de Chimie des Substances Naturelles, CNRS-ICSN UPR2301, Université Paris-Sud, Avenue de la Terrasse, 91198 Gif-sur-Yvette, France

b) Department of Chemistry, Wayne State University, 5101 Cass Avenue Detroit, MI 48202, USA

\section{dcrich@chem.wayne.edu; luis.bohe@cnrs.fr}

': Current address: School of Chemistry, The University of Manchester, Oxford Road, Manchester M13 9PL, UK.

\# Current address: Graduate School of Health Science, Hokkaido University, North 12, west 5 , kita-ku, Sapporo, 060-0812 Japan.

\begin{abstract}
The use of the 2-O-(2-trimethylsilylmethallyl) group as intramolecular nucleophile and cation clock reaction in the glucopyranose series depends on the nature of the glycosyl donor. As previously reported, with trichloroacetimidates the anticipated intramolecular Sakurai reaction proceeds efficiently and is an effective clock, whereas with sulfoxides complications arise. The source of these complications is now shown to be an intramolecular sulfenyl transfer reaction between the tethered allylsilane and the activated sulfoxide. These results illustrate how a different unimolecular clock reaction may be required for a given cation when it is generated from different donors in order to avoid side reactions. The synthesis and cyclization of a 2-O-(3hydroxypropyl) glucopyranosyl sulfoxide leading on activation to the formation of a trans-fused acetal is also described. The formation of this crystallographically-established trans-fused acetal is discussed in terms of the high effective concentration of the intramolecular nucleophile which
\end{abstract}


leads to a high degree of a $S_{N} 2$ character in the displacement of the $\alpha$-glucsoyl triflate or at the level of the corresponding $\alpha$-CIP. The possible use of such intramolecular alcohols as clock reactions and their limitations is discussed.

\section{Keywords}

cation clock, glycosylation, sulfoxide donor, sulfenyl transfer, tricyclic acetal

\section{Introduction.}

We have recently developed a cation clock method for probing the concentration dependence of the acceptor in glycosylation reactions. The clock reaction is based on the internal attack on the cationic center of a nucleophilic arm strategically bound to the donor. The concentration dependence of glycosylation is easily determined by performing simple competition reactions in which the putative transient oxocarbenium intermediate, generated on activation, is trapped either by cyclization (clock reaction, $a$ in Scheme 1) and/or by the acceptor (glycosylation reaction, $b$ in Scheme 1). A marked increase in the ratio of glycosylation to cyclization products with increasing acceptor concentration reveals an $\mathrm{S}_{\mathrm{N}} 2$-like associative mechanism. Alternatively, a glycosylation/cyclization ratio showing low acceptor concentration dependence is characteristic of an $\mathrm{S}_{\mathrm{N}} 1$-like dissociative mechanism. ${ }^{1,2}$ This method allows synthetic chemists to easily localize the mechanism of a given reaction in the $\mathrm{S}_{\mathrm{N}} 1-\mathrm{S}_{\mathrm{N}} 2$ continuum of mechanisms of glycosylation, ${ }^{3,4}$ which is helpful for a rational optimization of the stereoselectivity and the yield.

Scheme 1. The cation clock concept. ( $\mathrm{Nu}=\mathrm{O}, \mathrm{N}$, double bond, etc.; $\mathrm{X}=$ leaving group; $\mathrm{Z}=\mathrm{H}$ or electrophilic center)
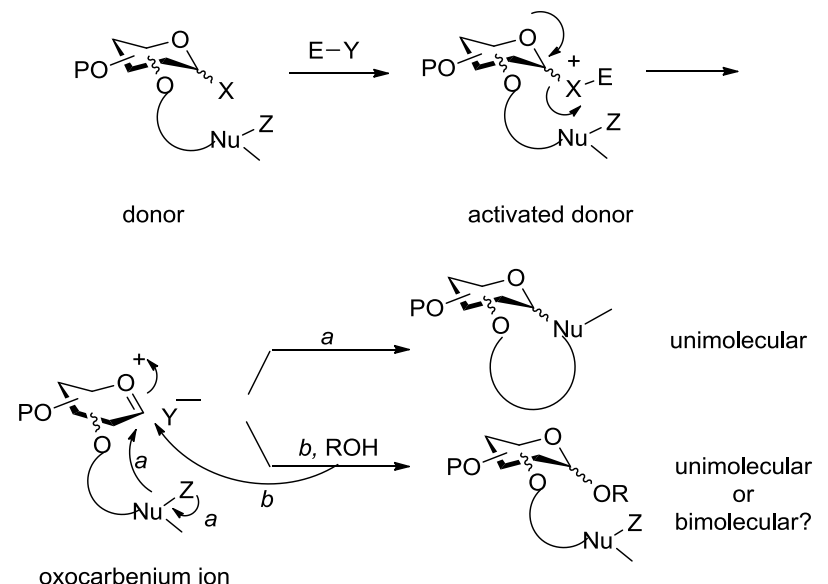
We developed the cation clock method by taking advantage of an intramolecular Sakurai reaction $^{5}$ to trap the oxocarbenium ion formed as intermediate in mannosylations and glucosylations. But beyond glycosylation, the concept of cyclization reactions as simple cation clocks for estimating the molecularity of nucleophilic attack on carbenium ions should find application in other cation-based reactions in the field of organic chemistry. Whatever the application, the clock reaction must be carefully chosen. The length of the nucleophilic arm and the nature of the nucleophile must allow easy internal attack (cyclization) on the cationic center while being practically inert toward other functionality in the substrate and compatible with the conditions for oxocarbenium ion formation from the precursors.

In the course of our study ${ }^{1,2}$ using pyranosyl sulfoxides as donors, ${ }^{6,7}$ we observed that a common nucleophilic arm, bound to $\mathrm{O} 2$ and bearing an allylsilane as the nucleophilic moiety, provided an efficient clock reaction for mannosylation reactions but not for the corresponding glucosylations. Nevertheless, the same tethered allylsilane allowed an efficient clock reaction for glucosylations using glucosyl trichloroacetimidates as donors, thus strongly suggesting that the clock reaction must be suitably harmonized with the substrate and the conditions of the reaction whose mechanism is being evaluated. We present here a rationalization for the different behavior of the allylsilane clock as a function of the donor in our glucosylation and mannosylation studies, which underlines the prominence of stereochemistry in reaction mechanisms. ${ }^{8}$ The results illustrate how a different unimolecular clock reaction may be required for a given cation when it is generated from different donors so as to avoid side reactions. ${ }^{9}$ We also introduce the concept of intramolecular hydroxyl groups as candidates for clock reactions leading to the formation of bicyclic acetals, and discuss the problems inherent in such systems with emphasis on the tether. We anticipate that these results will aid in the design of other cation clocks for the study of further glycosylation and other reactions.

\section{Results and discussion}

We have recently described the synthesis of donors 1-5 (Figure 1) and their behavior as cation clocks in the study of the molecularity of their $C$ - and $O$-glycosylations. ${ }^{2}$ The 4,6- $O$-benzylideneprotected trichloroacetimidates $\mathbf{1}$ and $\mathbf{4}$ worked efficiently as mannosylation and glucosylation clocks, cyclizing readily when activated with trimethylsilyl triflate. In the absence of an external 
acceptor, clock 1 led to the mannosyl derivatives $\mathbf{8}$ and $\mathbf{1 0}$ (Figure 1), isolated in $70 \%$ and $25 \%$ yields, respectively. Under the same conditions clock 4 led to the glucosyl derivative 12 (Figure 1) in $92 \%$ yield. Both the cis and the trans cyclized products $\mathbf{8}$ and $\mathbf{1 0}$ were formed from $\mathbf{1}$ whereas only the cis-cyclized product $\mathbf{1 2}$ was formed from 4.

Figure 1. Glycosyl donors and products from the corresponding clock reactions

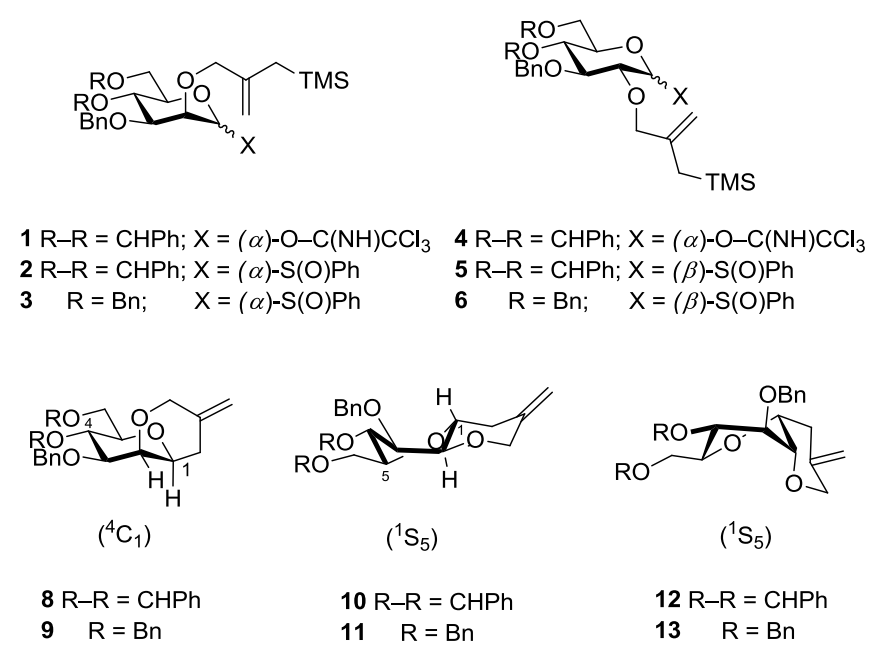

The 4,6-O-benzylidene-protected sulfoxide $\mathbf{2}$ also worked satisfactorily as a mannosylation clock. Upon activation with triflic anhydride it behaved like trichloroacetimidate 1, leading to the cyclized products $\mathbf{8}$ and $\mathbf{9}$, the cis-product $\mathbf{8}$ was isolated with a slightly lower yield (45\% vs 70 $\%$ from 1) and the anti-product 9 was isolated with the same yield as from 1 (25\%). In contrast, the glucosyl sulfoxide $\mathbf{5}$ failed to behave as an efficient clock owing to the formation of various byproducts. Thus, although activation of $\mathbf{5}$ with triflic anhydride led to the expected cyclization product 12, it was accompanied by the two anomers of the byproduct $\mathbf{1 4}$ in an approximate 1:1:1 mixture as revealed by ${ }^{1} \mathrm{H}$ NMR spectroscopy of the crude reaction mixture (Scheme 2). The requisite cyclization was therefore a minor path, with the major one leading to the formation of undesired side products formally resulting from hydrolysis of the glucosyl donor and incorporation of a phenyl sulfenyl residue on the $\mathrm{O} 2 \mathrm{arm}$. This major pathway could not be suppressed even working in the presence of a large excess of a sacrificial alkene (up to 30 equivalents of 1-octene or $\beta$-pinene), a known strategy ${ }^{10-12}$ to prevent a "sulfenyl group transfer" to substrate-based nucleophiles. Interestingly, attempted use of $\mathbf{5}$ in competition kinetics at -72 ${ }^{\circ} \mathrm{C}$ with isopropanol as acceptor in moderate excess (2.5-3 equiv) only led to products $\mathbf{1 2}$ and $\mathbf{1 4}$ 
in an almost 1:2 molar ratio (Scheme 2). The expected glycosylation products $\mathbf{1 5}$ could not be detected.

Scheme 2. Attempted clock reactions with the glucosyl sulfoxide $\mathbf{5}$.

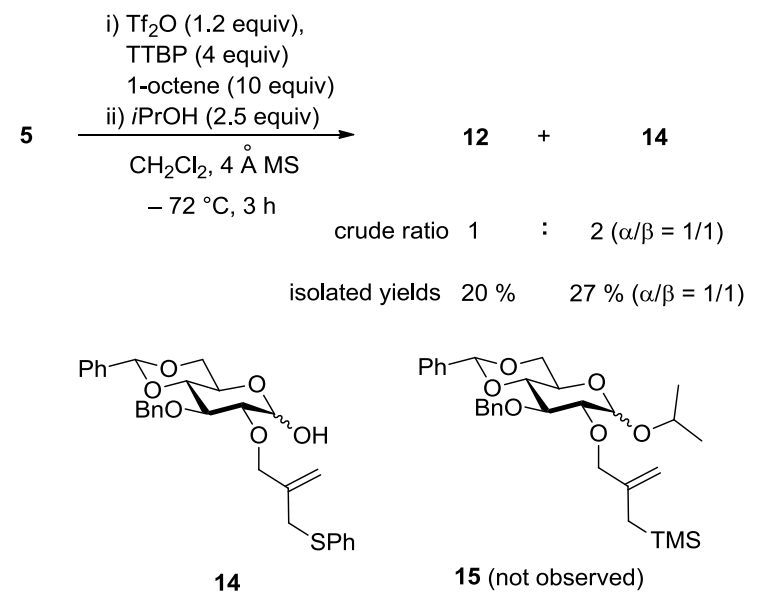

A similar behavior was observed with the more conformationally mobile glucosyl sulfoxide $\mathbf{6}$, prepared from phenyl 3,4,6-tri- $O$-benzyl- $\beta$-D-thioglycoside $\mathbf{1 6}^{13}$ as described in Scheme 3. Sequential saponification and alkylation with iodomethylallylsilane ${ }^{14}$ followed by controlled oxidation of thioglycoside 17 with $m \mathrm{CPBA}$ led to sulfoxide $\mathbf{6}$, as a 5:3 mixture of the $S_{\mathrm{R}}$ and $S_{\mathrm{S}}$ isomers in $61 \%$ yield.

Scheme 3. Synthesis of the glucosyl sulfoxide donor 6

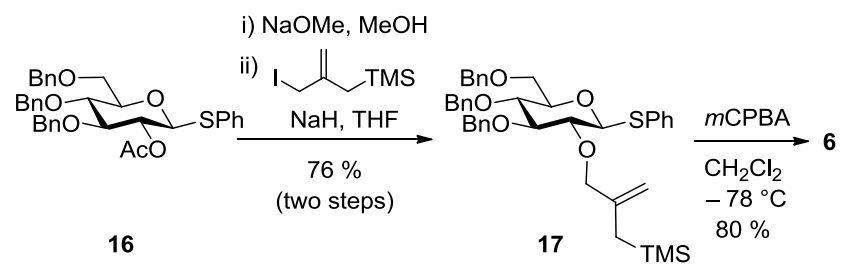

When donor 6 was activated by the addition of triflic anhydride at $-60{ }^{\circ} \mathrm{C}$ in the presence of isopropanol (1.5 equiv) a sulfenyl transfer also took place, as revealed by the formation of product 18, which was isolated in $34 \%$ yield. Albeit not the major process, the corresponding cyclization reaction of $\mathbf{6}$, like that of the benzylidene glucosyl donor $\mathbf{5}$, was highly stereoselective, and afforded only the cis-cyclized product 13, that was isolated in $37 \%$ yield. However, unlike the case of donor 5, the expected glycosylation product $\mathbf{1 9}$ was formed from $\mathbf{6}$ 
on activation in the presence of isopropanol even if only as a minor product isolated in a modest $14 \%$ yield (Scheme 4$)$.

Scheme 4. Attempted clock reactions with the glucosyl sulfoxide 6.

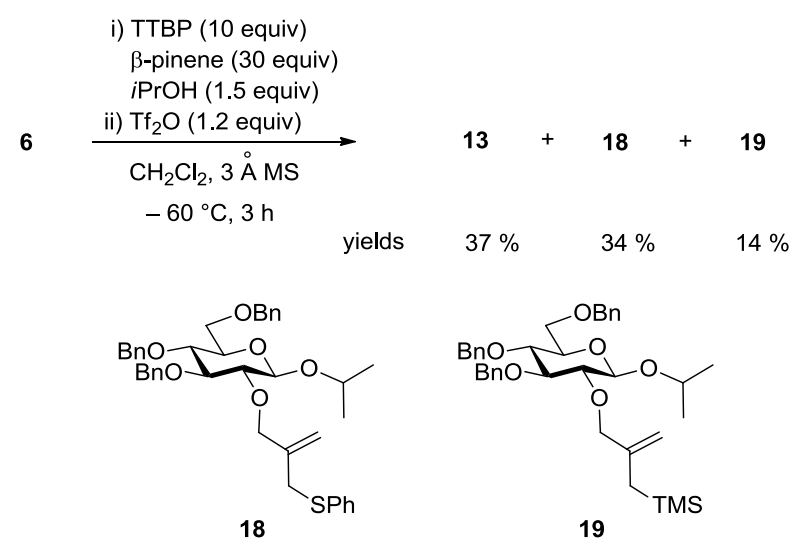

The inability of a large excess of alkene to prevent the formation of compounds $\mathbf{1 4}$ and $\mathbf{1 8}$ from donors $\mathbf{5}$ and $\mathbf{6}$, and the stark contrast with the mannosyl donors $\mathbf{2}$ and $\mathbf{3}$, strongly suggested an intramolecular sulfenyl transfer as the root of the problem. Such a transfer may be envisaged according to paths B and/or C in Scheme 5.

Scheme 5. Rationalization of sulfenyl transfer in glucose series

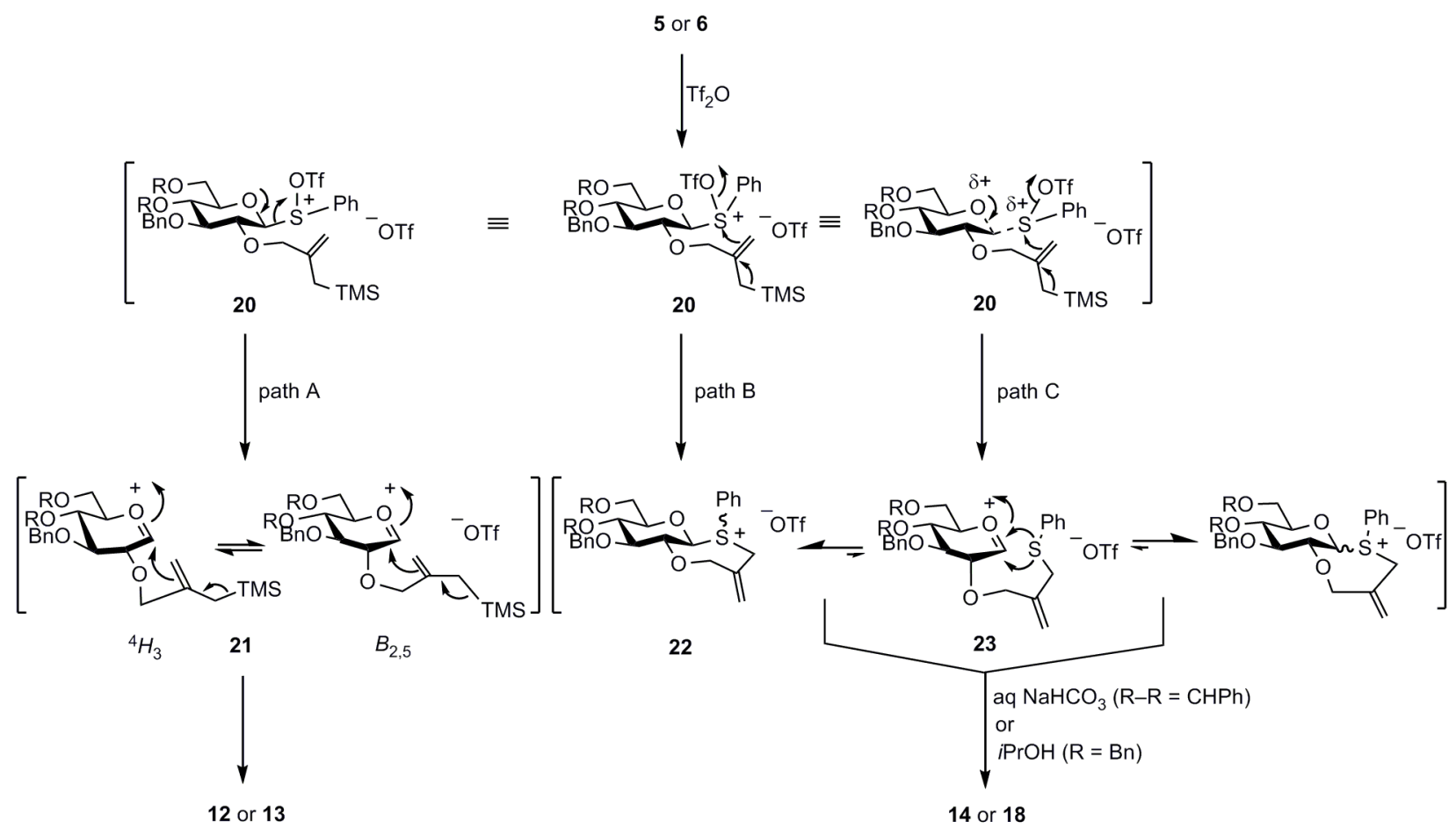


Thus, triflation of the glucosyl sulfoxide leads to a $S$-triflyloxy sulfonium salt $\mathbf{2 0}$. Cleavage of 20 to the oxocarbenium ion 21 (Scheme 5, path A) followed by a cyclization of the allylsilane onto $\mathrm{C} 1$ is responsible for the formation of the cyclized products. ${ }^{2}$ Alternatively, sulfenyl transfer results from an intramolecular nucleophilic attack by the allylsilane on the sulfur atom of the activated donor 20. This attack might occur directly on the glycosyl sulfonium ion leading to the cyclic glycosyl sulfonium ion 22 (Scheme 5, path B) or in concert with departure of benzenesulfenyl triflate that is intercepted by the allylsilane leading to the short-lived oxocarbenium 23 (Scheme 5, path C) followed by immediate recollapse leading to 22 , and possibly it's $\alpha$-anomer. Either way the immediate product is a cyclic glycosyl sulfonium ion. Subsequent hydrolysis on workup finally affords the observed products 14 or 18. Comparable six-membered cyclic sulfonium salts derived from glucopyranoses have been characterized at low temperatures ${ }^{15}$ and a particularly stable one has been isolated. ${ }^{16}$ Glycosyl sulfonium salts have been employed as glycosyl donors ${ }^{15-17}$ on warming to temperatures of $0{ }^{\circ} \mathrm{C}$ or higher. However, while $\alpha$-selectivity predominates, mechanistic studies ${ }^{16,18,19}$ are in favor of selective addition to oxocarbenium ions with which they are in equilibrium rather than $S_{N} 2$ mechanisms involving direct displacement of the sulfonium salt. ${ }^{15,17}$ Analogous six-membered selenonium ions have also been characterized by NMR at low temperature and used as glycosyl donors. ${ }^{20}$ Differences in the composition of product mixtures arising from the activation of $\mathbf{5}$ and $\mathbf{6}$ in the presence of isopropanol, with only 6 affording any isopropyl glycosides, are best explained by the change in the protection at the 4- and 6-positions. It is widely appreciated that the 4,6-Obenzylidene acetal group is more disarming than two correspondingly located benzyl ethers owing to a combination of torsional and electronic effects. ${ }^{21-23}$ Thus, the more stable oxocarbenium $23(\mathrm{R}=\mathrm{Bn})$ derived from $\mathbf{6}$ is populated to a greater extent in the equilibrium with the corresponding sulfonium salt, than the oxocarbenium $23(\mathrm{R}-\mathrm{R}=\mathrm{CHPh})$ derived from 5 that does not undergo reaction with isopropanol under the reaction conditions. Neither sulfonium ion, however, survives the work up process and both are converted to either the hydrolysis product 14 and/or the isopropyl glucoside $\mathbf{1 8}$ according to the work up conditions. Accordingly, in a reaction using donor 5 and conducted in the conditions of Scheme 2, the anomeric isopropyl $\alpha$ - and $\beta$ glycosides $\mathbf{2 4 \alpha}$ and $\mathbf{2 4 \beta}$ (Fig 2) were isolated in $14 \%$ and $26 \%$ yield, respectively, when additional isopropanol was added after the normal period of stirring at $-72{ }^{\circ} \mathrm{C}$ and the reaction 
mixture was allowed to warm to almost room temperature before quenching with aqueous bicarbonate.

The absence of a comparable sulfenyl transfer reaction with the mannosyl sulfoxides $\mathbf{2}$ and $\mathbf{3}$, which leaves them free to function as efficient mannosylation clocks, arises from the transdiaxial nature of the allylsilane and activated sulfoxide moieties.

Figure 2. Glycosylation products derived from donor $\mathbf{5}$

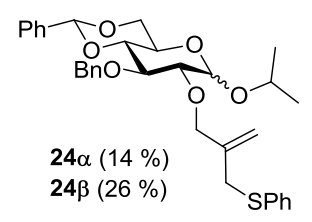

In view of the drawbacks of allylsilane clocks $\mathbf{5}$ and $\mathbf{6}$ in the study of glucosylations using sulfoxide donors, we investigated the use of an alternative hydroxyl-based nucleophilic arm. In view of the high nucleophilicity of alcohols compared to allylsilanes, we did not investigate the use of 2-O-(2-hydroxyethyl) systems as we considered that cyclization would be too rapid to allow the possibility of competition with external nucleophiles. Rather we focused on the use of a 2-O-(3-hydroxypropyl) arm anticipated to result in the formation of a seven-membered ring on cyclization. Thus, we prepared the glucosyl sulfoxide $\mathbf{2 8}$ (Scheme 6) from thioglycoside $\mathbf{2 5}^{24}$ by allylation with sodium hydride and allyl bromide giving the allyloxy thioglycoside $\mathbf{2 6}$. Hydroboration of $\mathbf{2 6}$ under standard conditions then afforded the 3-hydroxypropyloxy thioglycoside $\mathbf{2 7}$ in $\mathbf{7 2} \%$ yield. Low temperature oxidation of $\mathbf{2 7}$ with $m$ CPBA finally gave the target sulfoxide $\mathbf{2 8}$, as a 3:2 mixture of $S_{\mathrm{R}^{-}}$and $S_{\mathrm{S}}$-isomers, in $85 \%$ yield. Both isomers of $\mathbf{2 8}$ were isolated by flash chromatography and characterized with the stereochemistry at sulfur assigned on the basis of established criteria. ${ }^{25,26}$

Scheme 6. Synthesis of the glucosyl sulfoxide donor 28 


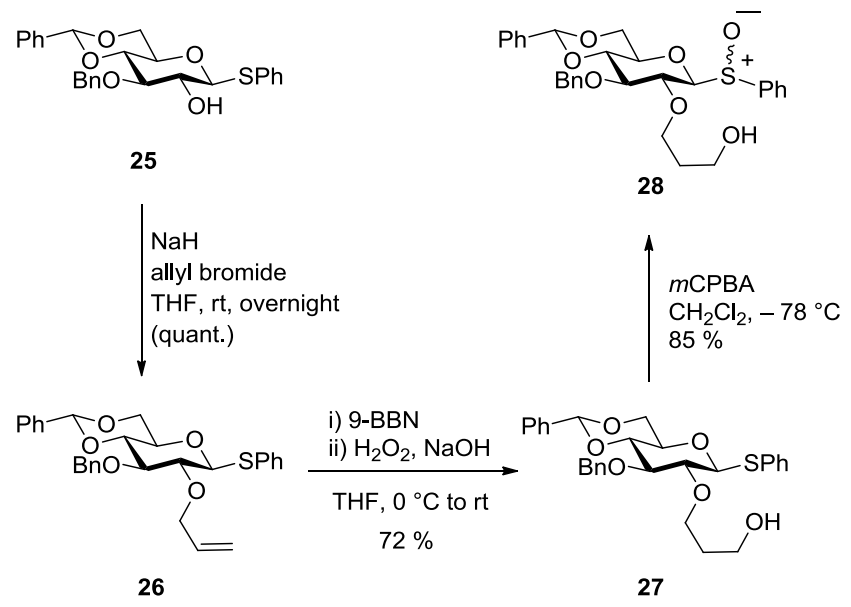

Exploratory cyclization reactions with donor $\mathbf{2 8}$ were conducted under the conditions already employed for the activation of donor $\mathbf{5}$. Thus, the glucosyl sulfoxide donor $\mathbf{2 8}$ was activated with triflic anhydride ( 1.5 equiv) in dichloromethane at $-72{ }^{\circ} \mathrm{C}$ in the presence of the non-nucleophilic base (TTBP, 6 equiv) and 1-octene in a large excess (10 equiv). The reaction mixture was stirred for $2.5 \mathrm{~h}$ at $-72{ }^{\circ} \mathrm{C}$ and then quenched at that temperature by the addition aqueous bicarbonate. Subsequent work up and flash chromatography afforded the tricyclic acetal 29 as the only cyclized product, isolated in $38 \%$ yield. The ${ }^{13} \mathrm{C}$ NMR spectrum of compound 29 exhibited the anomeric $\mathrm{C} 1$ resonance at $\delta 103.9$, slightly deshielded with respect to the benzylidene carbon at $\delta$ 101.5 , both in the characteristic domain of acetal carbons. The trans junction of the sevenmembered and the pyranose rings was strongly suggested by the ${ }^{1} \mathrm{H}$ NMR $\mathrm{H} 1$ signal at $\delta 4.7$, which is a doublet with a coupling constant $J_{\mathrm{H} 1-\mathrm{H} 2}$ of $7.9 \mathrm{~Hz}$. Further support for the trans-fused ring junction derives from the anomeric ${ }^{1} J_{\mathrm{C} 1-\mathrm{H}}$ coupling constant of $161.1 \mathrm{~Hz} .{ }^{27}$ Finally, the structure of 29 was confirmed by X-ray crystallographic analysis (CCDC 1446254). Interestingly, the crystal structure of $\mathbf{2 9}$, while unambiguously confirming the relative stereochemistry, was complicated by the presence of two conformers of the seven-membered ring as revealed by disorder in the location of the "glycosidic" oxygen and the two adjacent methylene groups. These two conformers (Fig. 3), statistically present in a ratio of $\sim 7: 3$, correspond to two chair conformations of the seven membered ring (see supplementary information).

The preferential formation of the trans-fused acetal 29, effectively a $\beta$-glucoside, is both interesting and noteworthy in view of the usual formation of $\alpha$-glucosides in intermolecular 4,6- 
$O$-benzylidene-mediated glucopyranosylation reactions. ${ }^{28-30}$ The formation of 29 presumably reflects a high degree of $S_{N} 2$-character in the displacement of the more stable $\alpha$-glucosyl triflate formed on activation, or in the attack on the corresponding $\alpha$-CIP with which the triflate is in equilibrium, and is a consequence of the intramolecular nature of the cyclization and the high effective molarity of the nucleophile. In the more common intermolecular glucosylations reaction occurs via less populated but more reactive $\beta$-triflate by a more open exploded transition state. $^{31}$

Figure 3. Structures of acetal 29 and isopropyl glucopyranosides 30, and X-Ray crystallographic structure of the two conformers of acetal $\mathbf{2 9}$ (major - top; minor - bottom).

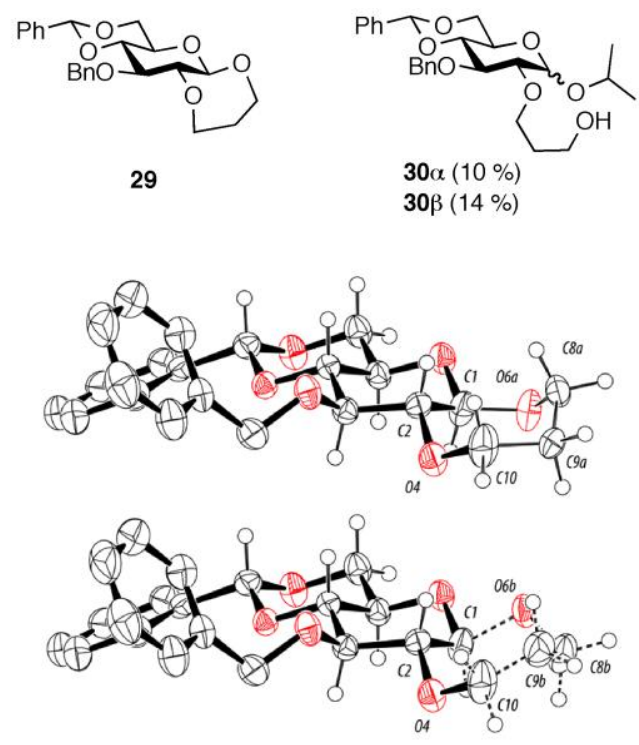

Competition kinetics were carried out with donor $\mathbf{2 8}$ under the conditions used for the cyclization to 29 but adding isopropanol as acceptor in moderate excess ( 2 equiv). This reaction afforded a mixture of products, from which the isopropyl $\alpha$ - and $\beta$-glucosides $30 \alpha$ and $30 \beta$ (Fig 3), were isolated in $10 \%$ and $14 \%$ yield respectively. Unfortunately however, analysis of the crude reaction mixture by UPLC/MS revealed that the expected cyclization and glucosylation products 29 and 30 were accompanied by the formation of disaccharides arising from intermolecular glycosylation of the hydroxypropyl group. The presence of such disaccharides suggested comparable rates for the reactions of the intermediate oxocarbenium with isopropanol and with the internal the hydroxylated residue of $\mathbf{2 8}$ (or of activated $\mathbf{2 8}$ ) under the conditions adopted for 
the competition reaction. The participation of the hydroxypropyl arm in intermolecular glycosylations in this manner prevents the use of $\mathbf{2 8}$ as an efficient glucosylation clock. Nevertheless, it remains possible that trapping by internal hydroxyl groups may eventually be suitable for use as clock reactions provided that the tether is designed to favor cyclization over intermolecular attack.

\section{Conclusion.}

The failure of the intramolecular allylsilane cation clock in glucopyranosylation by the sulfoxide method, as opposed to its smooth operation in the trichloroacetimidate method, is found to be the result of an intramolecular sulfenylation transfer reaction following activation of the sulfoxide with triflic anhydride. These results highlight the need for the clock reaction to be harmonized with the donor and the reaction conditions and demonstrate that different clock reactions may be required even for a given cation when it is generated from different donors so as to avoid side reactions. Attempted use of a nucleophilic 2-O-(3-hydroxypropyl) chain in a clock reaction in 4,6-O-benzylidene directed glucosylation results in the formation of a tricyclic acetal but is thwarted by competing intermolecular processes. The trans-fused nature of the acetal formed in this cyclization may be explained by a high degree of $\mathrm{S}_{\mathrm{N}} 2$ character in the ring closure, which is a function of the high effective molarity of the nucleophile. We anticipate that these results will aid in the design of other cation clocks for the study of further glycosylation and other reactions.

\section{Experimental section}

\subsection{General}

The experimental parts for compounds 1-5 and 8-12 can be found in the supporting information of references 1 and 2. Specific rotations were measured on an automatic polarimeter with a path length of $10 \mathrm{~cm}$. Melting points are uncorrected. High-resolution (HRMS) mass spectra were recorded in the electrospray mode using a time of flight mass analyzer (ESI-TOF). UHPLC analysis was performed with a C18 $1.7 \mu \mathrm{m}\left(2.1^{\circ}-50 \mathrm{~mm}\right)$ with the aid of mass and UV detectors.

\subsection{Cyclization of Glucosyl Sulfoxide (5)}


Phenyl 2- $O$-allyl-[(2-trimethylsilyl)methyl]-3- $O$-benzyl-4,6- $O$-benzylidene- $\beta$-D-glucopyranosyl sulfoxide 5 (90.8 g, $0.153 \mathrm{mmol})$ and anhydrous TTBP (155 mg, $0.62 \mathrm{mmol})$ were dissolved in freshly distilled dichloromethane $(9 \mathrm{~mL})$ under argon. Freshly activated molecular sieves ( $\mathrm{ca} .150$ mg, $4 \AA$, powdered) were added. The mixture was vigorously stirred and then cooled to $-72{ }^{\circ} \mathrm{C}$. Freshly distilled triflic anhydride $(38 \mu \mathrm{L}, 0.23 \mathrm{mmol})$ was added in one portion. The reaction mixture was stirred for a further $2.5 \mathrm{~h}$ at that temperature, and then saturated aqueous $\mathrm{NaHCO}_{3}(1$ $\mathrm{mL}$ ) was added to quench the reaction at $-72{ }^{\circ} \mathrm{C}$. The mixture was stirred again for a further $1 \mathrm{~h}$ at $-72{ }^{\circ} \mathrm{C}$, then warmed to room temperature. It was diluted with dichloromethane, and washed with saturated aqueous $\mathrm{NaHCO}_{3}$ and brine, dried over $\mathrm{Na}_{2} \mathrm{SO}_{4}$, filtered, and concentrated under reduced pressure. The crude product (143 mg, white solid) was purified by HPLC with a Eurospher 100-5 Si column (20×250 mm, AcOEt/Heptane 5/95 50/50, flow rate $18 \mathrm{~mL} / \mathrm{min})$, to give compound 12 as white solid (10.5 g, 17\%) and compounds 14a, $\boldsymbol{\beta}$ as a gel (21.4 mg, 27\%). Compound 12 was identical to the already described 1,5;4,8-bisanhydro-6-O-benzyl-7,9-Obenzylidene-2,3-dideoxy-2-methylene-D-glycero-D-ido-2-nonulose. Compounds $\mathbf{1 4 \alpha}$ and $\mathbf{1 4 \beta}$ were isolated by HPLC and characterized.

\subsection{2-O-[2-(Phenylthiomethyl)allyl]-3-O-benzyl-4,6-O-benzylidene- $\alpha$-D-glucopyranose (14 $\alpha)$ $R_{\mathrm{f}}=0.06\left(\right.$ EtOAc/Heptane, 20/80); ${ }^{1} \mathrm{H}$ NMR $\left(500 \mathrm{MHz}, \mathrm{CDCl}_{3}\right): \delta 7.19-7.51(\mathrm{~m}, 15 \mathrm{H}), 5.58(\mathrm{~s}$, 1H), $5.32(\mathrm{dd}, J=3.6 \mathrm{~Hz}, J=2.2 \mathrm{~Hz}, 1 \mathrm{H}), 5.11(\mathrm{~s}, 1 \mathrm{H}), 5.05(\mathrm{~s}, 1 \mathrm{H}), 4.92$ and $4.79(\mathrm{AB}, J=11.3$ $\mathrm{Hz}, 2 \mathrm{H}), 4.34(\mathrm{~s}, 2 \mathrm{H}), 4.31$ and $4.34(\mathrm{~m}, 1 \mathrm{H}), 4.09$ (apparent td, $J=5.0 \mathrm{~Hz}, J=10.0 \mathrm{~Hz}, 1 \mathrm{H})$, 3.97 (apparent t, $J=9.2 \mathrm{~Hz}, 1 \mathrm{H}), 3.67-3.59(\mathrm{~m}, 3 \mathrm{H}), 3.54\left(\mathrm{dd}, J=3.6 \mathrm{~Hz}, J_{2,3}=9.2 \mathrm{~Hz}, 1 \mathrm{H}\right), 3.14$ $(\mathrm{d}, J=2.2 \mathrm{~Hz}, 1 \mathrm{H}) ;{ }^{13} \mathrm{C} \mathrm{NMR}\left(75 \mathrm{MHz}, \mathrm{CDCl}_{3}\right): \delta 141.2,138.6,137.5,136.0,130.4,129.1$, 129.0, 128.5, 128.4, 128.2, 127.8, 126.7, 126.2, 116.7, 101.4, 92.0, 82.1, 79.5, 78.2, 75.3, 72.7, 69.2, 62.7, 37.5; ESIHRMS calcd for $\mathrm{C}_{30} \mathrm{H}_{32} \mathrm{O}_{6} \mathrm{NaS}[\mathrm{M}+\mathrm{Na}]^{+}$543.1817; found 543.1824.}

\subsection{2-O-[2-(Phenylthiomethyl)allyl]-3-O-benzyl-4,6-O-benzylidene- $\beta$-D-glucopyranose (14及)} $R_{\mathrm{f}}=0.06\left(\right.$ EtOAc/Heptane, 20/80); ${ }^{1} \mathrm{H} \mathrm{NMR}\left(500 \mathrm{MHz}, \mathrm{CDCl}_{3}\right): \delta 7.18-7.51(\mathrm{~m}, 15 \mathrm{H}), 5.59(\mathrm{~s}$, $1 \mathrm{H}), 5.13(\mathrm{~s}, 1 \mathrm{H}), 5.05(\mathrm{~s}, 1 \mathrm{H}), 4.94$ and $4.81(\mathrm{AB}, J=11.4 \mathrm{~Hz}, 2 \mathrm{H}), 4.78(\mathrm{dd}, J=8.0 \mathrm{~Hz}, J=5.6$ $\mathrm{Hz}, 1 \mathrm{H}), 4.48$ and $4.44(\mathrm{AB}, J=11.9 \mathrm{~Hz}, 2 \mathrm{H}), 4.37(\mathrm{dd}, J=5.0 \mathrm{~Hz}, J=10.5 \mathrm{~Hz}, 1 \mathrm{H}), 3.80$ (apparent t, $J=10.3 \mathrm{~Hz}, 1 \mathrm{H}), 3.70-3.77(\mathrm{~m}, 2 \mathrm{H}), 3.69$ and $3.65(\mathrm{AB}, J=13.7 \mathrm{~Hz}, 2 \mathrm{H}), 3.48$ (apparent td, $J=5.0 \mathrm{~Hz}, J=9.5 \mathrm{~Hz}, 1 \mathrm{H}), 3.41(\mathrm{~d}, J=5.6 \mathrm{~Hz}, 1 \mathrm{H}), 3.33$ (apparent t, $1 \mathrm{H}, J=8.0$ 
$\mathrm{Hz}) ;{ }^{13} \mathrm{C}$ NMR $\left(75 \mathrm{MHz}, \mathrm{CDCl}_{3}\right): \delta 141.7,138.5,137.4,136.2,130.2,129.1,128.9,128.5,128.4$, 128.2, 127.8, 126.5, 126.1, 116.4, 101.3, 97.9, 82.8, 81.8, 80.9, 75.2, 74.3, 68.8, 66.4, 37.4;

ESIHRMS calcd for $\mathrm{C}_{30} \mathrm{H}_{32} \mathrm{O}_{6} \mathrm{NaS}[\mathrm{M}+\mathrm{Na}]^{+}$543.1817; found 543.1824.

\subsection{Synthesis of glucosyl sulfoxide donor 6 \\ 4.5.1. Phenyl 2-O-[2-(Trimethysilylmethyl)allyl]-3,4,6-tri-O-benzyl-1-thio- $\beta$-D-glycopyranoside (17)}

To a stirred solution of phenyl 2- $O$-acetyl-3,4,6-tri- $O$-benzyl-1-thio- $\beta$-D-glycopyranoside 16 (2.0 $\mathrm{g}, 3.42 \mathrm{mmol})$ in methanol $(70 \mathrm{~mL})$, in a round-bottomed flask equipped with a condenser, sodium methoxide (37 mg, $0.68 \mathrm{mmol}$ ) was added and the mixture stirred at $80^{\circ} \mathrm{C}$ overnight. Then the reaction mixture was allowed to reach room temperature, neutralized with Amberlyst 15 resin to $\mathrm{pH} 7$, filtered and concentrated. The resulting mixture was co-evaporated with toluene 3 times and kept in vacuo for $2 \mathrm{~h}$. The crude product was dissolved in anhydrous THF (15 mL), $\mathrm{NaH}$ (411 mg, 60\% mineral oil dispersion) was added at $0{ }^{\circ} \mathrm{C}$ under argon. After $20 \mathrm{~min}, 2-$ iodomethyl-3-trimethylsilyl-1-propane $(4.11 \mathrm{~g}, 16.2 \mathrm{mmol})$ was added and the mixture stirred overnight at room temperature. The reaction mixture was diluted with diethyl ether, washed with sat. $\mathrm{Na}_{2} \mathrm{~S}_{2} \mathrm{O}_{3}$ and brine, dried over $\mathrm{Na}_{2} \mathrm{SO}_{4}$, filtered and concentrated. The crude mixture was purified by silica-gel chromatography (hexane/diethyl ether $=20 / 1 \sim 10 / 1$ containing $0.5 \%$ triethylamine) to give $\mathbf{1 7}$ as a white solid (1.75 g, 76\%) $[\alpha]^{\mathrm{RT}}{ }_{\mathrm{D}}-25.8\left(c\right.$ 2.30, $\left.\mathrm{CH}_{2} \mathrm{Cl}_{2}\right) ;{ }^{1} \mathrm{H}$ NMR $\left(500 \mathrm{MHz}, \mathrm{CD}_{2} \mathrm{Cl}_{2}\right) \delta$ 7.59-7.58 (m, $\left.2 \mathrm{H}\right)$, 7.40-7.24 (m, 18 H), 5.03 (br s, $1 \mathrm{H}$ ), 4.97-4.95 (d, $1 \mathrm{H}, J=11.0 \mathrm{~Hz}$ ), 4.88-4.85 (m, $2 \mathrm{H}), 4.74$ (br s, $1 \mathrm{H}), 4.72-$ $4.70(\mathrm{~d}, 1 \mathrm{H}, J=9.7 \mathrm{~Hz}), 4.64-4.61(\mathrm{~m}, 2 \mathrm{H}), 4.57-4.54(\mathrm{~d}, 1 \mathrm{H}, J=11.9 \mathrm{~Hz}), 4.31-4.29$ (d, $1 \mathrm{H}, J$ $=11.9 \mathrm{~Hz}), 4.14-4.12(\mathrm{~d}, 1 \mathrm{H}, J=11.9 \mathrm{~Hz}), 3.82-3.80(\mathrm{dd}, 1 \mathrm{H}, J=1.2,10.7 \mathrm{~Hz}), 3.76-3.72(\mathrm{~m}, 1$ H), 3.72-3.69 (t, $1 \mathrm{H}, J=8.8 \mathrm{~Hz}), 3.66-3.62(\mathrm{t}, 1 \mathrm{H}, J=9.3 \mathrm{~Hz}), 3.55-3.52(\mathrm{~m}, 1 \mathrm{H}), 3.42-3.39$ (t, $1 \mathrm{H}, J=9.1 \mathrm{~Hz}), 1.71-1.69(\mathrm{~d}, 1 \mathrm{H}, J=13.4 \mathrm{~Hz}), 1.57-1.54(\mathrm{~d}, 1 \mathrm{H}, J=13.4 \mathrm{~Hz}),-0.06$ (s, $9 \mathrm{H})$;

${ }^{13} \mathrm{C}$ NMR $\left(125 \mathrm{MHz}, \mathrm{CD}_{2} \mathrm{Cl}_{2}\right) \delta 144.5,139.2,128.8,134.9,131.6,129.3,128.72,128.69,128.67$, $128.29,128.17,128.14,128.05,127.95,127.89,127.57,108.9,87.9,86.9,81.4,79.3,78.1,77.4$, 75.8, 75.3, 73.7, 69.6, 23.8, -1.2; ESIHRMS calcd for $\mathrm{C}_{40} \mathrm{H}_{48} \mathrm{O}_{5} \mathrm{SSiNa}[\mathrm{M}+\mathrm{Na}]^{+}, 691.2889$; found 691.2893 . 
4.5.2 Phenyl 2-O-[2-(trimethysilylmethyl)allyl]-3,4,6-tri-O-benzyl-1-thio- $\beta$-D-glucopyranosyl sulfoxide (6)

To a solution of thioglycoside $\mathbf{1 5}(1.64 \mathrm{~g}, 2.45 \mathrm{mmol})$ in anhydrous dichloromethane $(50 \mathrm{~mL})$, meta-chloroperbenzoic acid (578 $\mathrm{mg}, 2.58 \mathrm{mmol}: 77 \%$ ) was added in portions at $-78{ }^{\circ} \mathrm{C}$ under argon. After $1 \mathrm{~h}$, the reaction mixture was allowed to reach to $-40{ }^{\circ} \mathrm{C}$ and stirred for additional $1.5 \mathrm{~h}$. Then, the reaction was neutralized with sat. $\mathrm{NaHCO}_{3}(100 \mathrm{~mL})$ and then allowed to reach room temperature. The mixture was extracted with dichloromethane, washed with brine, dried over $\mathrm{Na}_{2} \mathrm{SO}_{4}$, filtered and concentrated. The crude product was purified by silica-gel chromatography (hexane/ethyl acetate $=10 / 1 \sim 4 / 1$ containing $0.5 \%$ triethylamine) to give sulfoxides $\left(\boldsymbol{S}_{\mathbf{R}}\right)-\mathbf{6}\left(0.84 \mathrm{~g}, 50 \%\right.$, colorless syrup) and $\left(\boldsymbol{S}_{\mathbf{S}}\right)-\mathbf{6}(0.50 \mathrm{~g}, 30 \%$, white solid $)$. $\left(\boldsymbol{S}_{\mathbf{R}}\right)-\mathbf{6}:[\alpha]^{\mathrm{RT}}-172\left(c \mathrm{1} .35, \mathrm{CH}_{2} \mathrm{Cl}_{2}\right) ;{ }^{1} \mathrm{H}$ NMR $\left(500 \mathrm{MHz}, \mathrm{CD}_{2} \mathrm{Cl}_{2}\right) \delta$ 7.68-7.66 (m, $\left.2 \mathrm{H}\right), 7.53-$ 7.46 (m, 3 H), 7.40-7.21 (m, 15H), 5.07 (br s, 1H), 4.99-4.97 (d, 1H, J = 11.0 Hz), 4.93-4.90 (d, $1 \mathrm{H}, J=11.0 \mathrm{~Hz}), 4.94-4.82(\mathrm{~d}, 1 \mathrm{H}, J=11.0 \mathrm{~Hz}), 4.78(\mathrm{br} \mathrm{s}, 1 \mathrm{H}), 4.61-4.59(\mathrm{~d}, 1 \mathrm{H}, J=11.0 \mathrm{~Hz})$, 4.41-4.38 (d, 1H, $J=12.2 \mathrm{~Hz}$ ), 4.37 (br s, 2H), 4.32-4.29 (d, 1H, $J=12.2 \mathrm{~Hz}), 4.00-3.98$ (d, 1H, $J=9.8 \mathrm{~Hz}$ ), 3.95-3.91 (t, $1 \mathrm{H}, J=9.8,8.8 \mathrm{~Hz}), 3.81-3.77$ (t, $1 \mathrm{H}, J=8.8 \mathrm{~Hz}), 3.64-3.60$ (t, $1 \mathrm{H}, J=$ 9.8, 9.2 Hz), 3.58-3.55 (dd, $1 \mathrm{H}, J=4.9,11.3 \mathrm{~Hz}), 3.50-3.47(\mathrm{dd}, 1 \mathrm{H}, J=1.6,11.3 \mathrm{~Hz}), 3.33-3.30$ $(\mathrm{m}, 1 \mathrm{H}), 1.7-1.71(\mathrm{~d}, 1 \mathrm{H}, J=13.7 \mathrm{~Hz}), 1.61-1.58(\mathrm{~d}, 1 \mathrm{H}, J=13.7 \mathrm{~Hz}),-0.08(\mathrm{~s}, 9 \mathrm{H}) ;{ }^{13} \mathrm{C}-\mathrm{NMR}$ $\left(125 \mathrm{MHz}, \mathrm{CD}_{2} \mathrm{Cl}_{2}\right) \delta 144.3,140.6,138.9,138.7,138.5,131.2,129.1,128.7,128.7,138.3$, 128.12 , 128.09, 128.02, 127.94, 127.89, 125.6, 109.2, 93.9, 86.7, 80.6, 77.7, 77.6, 77.1, 75.7, 75.3, 73.7, 69.0, 23.7, -1.26; ESIHRMS calcd for $\mathrm{C}_{40} \mathrm{H}_{48} \mathrm{O}_{6} \mathrm{SSiNa}[\mathrm{M}+\mathrm{Na}]^{+}, 707.2839$; found 707.2841 .

$\left(S_{\mathrm{S}}\right)-6:[\alpha]_{\mathrm{D}}{ }^{\mathrm{RT}}+2.2\left(c 0.60, \mathrm{CH}_{2} \mathrm{Cl}_{2}\right) ;{ }^{1} \mathrm{H}$ NMR $\left(500 \mathrm{MHz}, \mathrm{CD}_{2} \mathrm{Cl}_{2}\right) \delta 7.70-7.68(\mathrm{~m}, 2 \mathrm{H}), 7.47-$ $7.45(\mathrm{~m}, 3 \mathrm{H}), 7.37-7.26(\mathrm{~m}, 13 \mathrm{H}), 7.20-7.18(\mathrm{~m}, 2 \mathrm{H}), 4.83-7.79(\mathrm{~m}, 3 \mathrm{H}), 4.74-4.72(\mathrm{~d}, 1 \mathrm{H}, J=$ $11.0 \mathrm{~Hz}$ ), 4.64 (br s, 1H), 4.57-4.55 (d, 1H, $J=11.0 \mathrm{~Hz}$ ), 4.47 (s, 2H), 4.45-4.43 (d, 1H, $J=8.2$ $\mathrm{Hz}), 4.13$ (s, 2H), 3.79-3.76 (t, 1H, $J=7.6 \mathrm{~Hz}), 3.71-3.67$ (m, 3H), 3.64-3.56 (m, 2H), 1.55-1.52 $(\mathrm{d}, 1 \mathrm{H}, J=13.7 \mathrm{~Hz}), 1.45-1.42(\mathrm{~d}, 1 \mathrm{H}, J=13.8 \mathrm{~Hz}),-0.02(\mathrm{~s}, 9 \mathrm{H}) ;{ }^{13} \mathrm{C}-\mathrm{NMR}\left(125 \mathrm{MHz}, \mathrm{CD}_{2} \mathrm{Cl}_{2}\right)$ $\delta 143.7,141.2,138.7,138.6,131.4,129.1,128.7,128.2,128.1,127.98,127.96,126.0,108.6$, 95.8, 85.9, 79.2, 77.6, 76.6, 75.9, 75.1, 74.9, 73.8, 69.1, 23.7, -1.2; ESIHRMS calcd for $\mathrm{C}_{40} \mathrm{H}_{48} \mathrm{O}_{6} \mathrm{SSiNa}[\mathrm{M}+\mathrm{Na}]^{+}, 707.2839$; found 707.2834.

\subsection{Competitive glycosylation using donor 6}


Sulfoxide 6 (46 mg, $67.2 \mu \mathrm{mol}$ ) and 2,4,6-tri-tert-butyl pyrimidine (167 mg, $672.2 \mu \mathrm{mol}$ ) were co-evaporated with toluene 3 times and kept in vacuo overnight. Then, acid-wash molecular sieves $3 \AA ̊$ (120 mg), 2-propanol (7.8 $\mu \mathrm{L}, 100.8 \mu \mathrm{mol}), \beta$-pinene (275 mg, $2.02 \mathrm{mmol})$ and anhydrous dichloromethane $(3.5 \mathrm{~mL})$ were added and the mixture stirred for $1 \mathrm{~h}$ at room temperature under argon. The reaction mixture was cooled to $-60{ }^{\circ} \mathrm{C}$, kept stirring for $1 \mathrm{~h}$ and then triflic anhydride $(13.6 \mu \mathrm{L}, 80.7 \mu \mathrm{mol})$ was added. The reaction mixture was stirred for $3 \mathrm{~h}$ at $-60{ }^{\circ} \mathrm{C}$, then neutralized with triethylamine $(50 \mu \mathrm{L})$ and then allowed to reach to room temperature. The reaction mixture was diluted with EtOAc, washed with water, sat. $\mathrm{NaHCO}_{3}$, brine, dried over $\mathrm{Na}_{2} \mathrm{SO}_{4}$, filtered and concentrated. The crude product was purified by silica-gel chromatography (hexane/ethyl acetate $=50 / 1 \sim 3 / 1$ containing $0.5 \%$ triethylamine) to give bicyclic $\mathbf{1 7}$ as a colorless oil (12 $\mathrm{mg}, 37 \%$ ), the phenylthiomethallyl isopropyl glucoside $\mathbf{1 8}$ as a colorless oil (15 mg, 34\%) and the trimethylsilylmethallyl isopropylglucoside $\mathbf{1 9}$ as a light white oil (6 mg, $14 \%)$.

4.6.1 Isopropyl 2-O-[2-(2-Phenylthiomethyl)allyl]-3,4,6-tri-O-benzyl- $\beta$-D-glycopyranoside (18) $[\alpha]^{\mathrm{RT}}+0.8\left(c 0.75, \mathrm{CH}_{2} \mathrm{Cl}_{2}\right) ;{ }^{1} \mathrm{H}$ NMR $\left(600 \mathrm{MHz}, \mathrm{CD}_{2} \mathrm{Cl}_{2}\right) \delta$ 7.34-7.27 (m, 20H), $5.10(\mathrm{br} \mathrm{s}, 1 \mathrm{H})$, 5.00 (br s, $1 \mathrm{H}), 4.89$ (d, 1H, J = 11.0 Hz), 4.80-4.77 (m, 2H), 4.59-4.50 (m, 4H), 4.41-4.40 (d, $1 \mathrm{H}, J=7.7 \mathrm{~Hz}), 4.30-4.28(\mathrm{~d}, 1 \mathrm{H}, J=12.1 \mathrm{~Hz}), 3.99-3.95(\mathrm{q}, 1 \mathrm{H}, J=6.3 \mathrm{~Hz}), 3.73-3.71(\mathrm{dd}, 1 \mathrm{H}$, $J=1.8,10.6 \mathrm{~Hz}$ ), 3.69-3.67 (dd, $1 \mathrm{H}, J=4.4,10.6 \mathrm{~Hz}), 3.61(\mathrm{~s}, 2 \mathrm{H}), 3.57-3.54(\mathrm{t}, 1 \mathrm{H}, J=8.0 \mathrm{~Hz})$, $3.42-3.40(\mathrm{~m}, 1 \mathrm{H}), 3.26-3.23(\mathrm{t}, 1 \mathrm{H}, J=8.5 \mathrm{~Hz}), 1.25-1.24(\mathrm{~d}, 3 \mathrm{H}, J=6.2 \mathrm{~Hz}), 1.19-1.18(\mathrm{~d}, 3 \mathrm{H}$, $J=6.3 \mathrm{~Hz}) ;{ }^{13} \mathrm{C}-\mathrm{NMR}\left(150 \mathrm{MHz}, \mathrm{CD}_{2} \mathrm{Cl}_{2}\right) \delta 142.5,138.9,136.7,130.1,129.1,128.7,128.6$, 128.3, 128.2, 128.1, 128.0, 127.9, 127.8, 126.4, 115.5, 102.2, 85.1, 82.0, 78.4, 75.7, 75.2, 75.1, 73.7, 73.6, 72.2, 69.6, 37.3, 23.9, 22.2; ESIHRMS calcd for $\mathrm{C}_{40} \mathrm{H}_{46} \mathrm{O}_{6} \mathrm{SNa}[\mathrm{M}+\mathrm{Na}]^{+}, 677.2913$; found 677.2901 .

4.6.2. Isopropyl 2-O-[2-(Trimethylsilylmethyl)allyl]-3,4,6-tri-O-benzyl- $\beta$-D-glucopyranoside (19) $[\alpha]^{\mathrm{RT}}{ }_{\mathrm{D}}+0.5\left(c 1.30, \mathrm{CH}_{2} \mathrm{Cl}_{2}\right) ;{ }^{1} \mathrm{H}$ NMR $\left(600 \mathrm{MHz}, \mathrm{CD}_{2} \mathrm{Cl}_{2}\right) \delta$ 7.36-7.25 (m, 13H) 7.21-7.20 (m, 2H), 4.97 (br s, 1H), 4.94-4.93 (d, 1H, $J=11.0 \mathrm{~Hz}), 4.82-4.81$ (d, 1H, $J=10.6 \mathrm{~Hz}), 4.79-4.77$ (d, $1 \mathrm{H}, J=11.0 \mathrm{~Hz}), 4.66(\mathrm{br} \mathrm{s}, 1 \mathrm{H}), 4.60-4.52(\mathrm{~m}, 3 \mathrm{H}), 4.42-4.41(\mathrm{~d}, 1 \mathrm{H}, J=7.7 \mathrm{~Hz}), 4.30-4.28(\mathrm{~d}$, $1 \mathrm{H}, J=12.5 \mathrm{~Hz}), 4.03-4.01(\mathrm{~d}, 1 \mathrm{H}, J=12.9 \mathrm{~Hz}), 4.00-3.96(\mathrm{~m}, 1 \mathrm{H}), 3.73-3.72(\mathrm{dd}, 1 \mathrm{H}, J=1.5$, $10.6 \mathrm{~Hz}), 3.69-3.67(\mathrm{dd}, 1 \mathrm{H}, J=4.8,10.7 \mathrm{~Hz}), 3.60-3.57(\mathrm{t}, 1 \mathrm{H}, J=9.2 \mathrm{~Hz}), 3.55-3.52(\mathrm{t}, 1 \mathrm{H}, J=$ 
$9.5 \mathrm{~Hz}), 3.43-3.40(\mathrm{~m}, 1 \mathrm{H}), 3.24-3.21(\mathrm{t}, 1 \mathrm{H}, J=8.0 \mathrm{~Hz}), 1.26-1.25(\mathrm{~d}, 3 \mathrm{H}, J=5.9 \mathrm{~Hz}), 1.20-1.19$ $(\mathrm{d}, 3 \mathrm{H}, J=6.2 \mathrm{~Hz}),-0.01(\mathrm{~s}, 9 \mathrm{H}) ;{ }^{13} \mathrm{C}-\mathrm{NMR}\left(150 \mathrm{MHz}, \mathrm{CD}_{2} \mathrm{Cl}_{2}\right) \delta 144.9,139.4,139.0,138.9$, 128.7, 128.64, 128.60, 128.28, 128.26, 128.22, 128.18, 128.15, 128.1, 127.96, 127.89, 127.77, $108.6,102.2,85.1,82.6,78.3,76.8,75.7,75.2,75.0,73.7,72.0,69.6,30.1,23.9,22.2,-1.3$; ESIHRMS calcd for $\mathrm{C}_{37} \mathrm{H}_{50} \mathrm{O}_{6} \mathrm{Na}[\mathrm{M}+\mathrm{Na}]^{+}, 641.3274$; found 641.3286 .

\subsection{Competitive glycosylation using donor 5 , quenching with isopropanol at $-72{ }^{\circ} \mathrm{C}$}

Compound 5 (51.7 mg, $0.0872 \mathrm{mmol})$ and anhydrous TTBP ( $88 \mathrm{mg}, 0.354 \mathrm{mmol})$ were dissolved in freshly distilled dichloromethane $(5 \mathrm{~mL})$ under argon. Freshly activated molecular sieves ( $c a$. $150 \mathrm{mg}, 4 \AA$, powdered) were then added. The mixture was vigorously stirred and then cooled to $-72{ }^{\circ} \mathrm{C}$. Freshly distilled triflic anhydride $(22 \mu \mathrm{L}, 0.131 \mathrm{mmol})$ was added in one portion. The reaction mixture was stirred for $8 \mathrm{~min}$ and distilled isopropanol $(13.5 \mu \mathrm{L}, 0.175 \mathrm{mmol})$ was added. The reaction mixture was stirred for a further $2.5 \mathrm{~h}$ at that temperature, and then distilled isopropanol $(1 \mathrm{~mL})$ was added to quench the reaction at $-72{ }^{\circ} \mathrm{C}$. The mixture was stirred again for a further $1 \mathrm{~h}$ at $-72{ }^{\circ} \mathrm{C}$, then warmed to room temperature. It was diluted with dichloromethane, and washed with saturated aqueous $\mathrm{NaHCO}_{3}$ and brine, dried over $\mathrm{Na}_{2} \mathrm{SO}_{4}$, filtered, and concentrated under reduced pressure. The crude (190 mg, white solid) was purified by HPLC (Eurospher 100-5 Si column 20×250 mm, EtOAc/Heptane: 5/95 50/50, flow rate 18 $\mathrm{mL} / \mathrm{min}$ ), to give compound $\mathbf{2 4} \boldsymbol{\alpha}$ as colorless oil (7 $\mathrm{mg}, 14 \%$ ) and compound $\mathbf{2 4 \beta}$ as colorless oil (13 mg, 26\%).

\subsubsection{Isopropyl 2-O-[2-(Phenylthiomethyl)allyl]-3-O-benzyl-4,6-O-benzylidene- $\alpha$-D-glucoside $(24 \alpha)$}

$[\alpha]^{25}+10\left(c=1, \mathrm{CHCl}_{3}\right) ; R_{\mathrm{f}}=0.4($ EtOAc/Heptane, $20 / 80) ;{ }^{1} \mathrm{H} \mathrm{NMR}\left(500 \mathrm{MHz}, \mathrm{CDCl}_{3}\right): \delta$ 7.19-7.53 (m, 15H), $5.60(\mathrm{~s}, 1 \mathrm{H}), 5.13(\mathrm{~s}, 1 \mathrm{H}), 5.05(\mathrm{~s}, 1 \mathrm{H}), 5.04(\mathrm{br} \mathrm{s}, 1 \mathrm{H}), 4.93$ and $4.83(\mathrm{AB}, J$ $=11.1 \mathrm{~Hz}, 2 \mathrm{H}), 4.35$ and $4.31(\mathrm{AB}, J=12.3 \mathrm{~Hz}, 2 \mathrm{H}), 4.30(\mathrm{dd}, J=5.1 \mathrm{~Hz}, J=10.1 \mathrm{~Hz}, 1 \mathrm{H}), 4.04$ (at, $J=9.3 \mathrm{~Hz}, 1 \mathrm{H}), 3.92-3.99(\mathrm{~m}, 2 \mathrm{H}), 3.75$ (apparent t $J=10.1 \mathrm{~Hz}, 1 \mathrm{H}), 3.62-3.68(\mathrm{~m}, 3 \mathrm{H}, \mathrm{H}-$ 4), 3.52 (apparent td, $J=3.8 \mathrm{~Hz}, J=9.3 \mathrm{~Hz}, 1 \mathrm{H}), 1.29(\mathrm{~d}, J=6.2 \mathrm{~Hz}, 3 \mathrm{H}), 1.22(\mathrm{~d}, J=6.2 \mathrm{~Hz}$, $3 \mathrm{H}) ;{ }^{13} \mathrm{C} \mathrm{NMR}\left(75 \mathrm{MHz}, \mathrm{CDCl}_{3}\right): \delta 141.6,140.0,137.6,136.2,130.3,129.0,128.9,128.43$, 128.36, 128.1, 127.7, 126.5, 126.2, 116.3, 101.3, 96.1, 82.6, 79.4, 78.7, 75.4, 72.5, 70.2, 69.3, 62.6, 37.3, 23.5, 21.6; ESIHRMS calcd for $\mathrm{C}_{33} \mathrm{H}_{42} \mathrm{NO}_{6} \mathrm{~S}\left[\mathrm{M}+\mathrm{NH}_{4}\right]^{+}$580.2733; found 580.2728. 


\subsubsection{Isopropyl 2-O-[2-(Phenylthiomethyl)allyl]-3-O-benzyl-4,6-O-benzylidene- $\beta$-D-glucoside}

(24及) $[\alpha]^{27}{ }_{\mathrm{D}}-50\left(c=1, \mathrm{CHCl}_{3}\right) ; R_{\mathrm{f}}=0.5($ EtOAc/Heptane, $20 / 80) ;{ }^{1} \mathrm{H} \mathrm{NMR}\left(500 \mathrm{MHz}, \mathrm{CDCl}_{3}\right): \delta$ 7.15-7.49 (m, 15H), $5.55(\mathrm{~s}, 1 \mathrm{H}), 5.10(\mathrm{~s}, 1 \mathrm{H}), 5.01(\mathrm{~s}, 1 \mathrm{H}), 4.90$ and $4.78(\mathrm{AB}, J=11.5 \mathrm{~Hz}, 2 \mathrm{H})$, $4.51(\mathrm{dd}, J=8.1 \mathrm{~Hz}, 1 \mathrm{H}), 4.49$ and $4.35(\mathrm{AB}, J=12.0 \mathrm{~Hz}, 2 \mathrm{H}), 4.31-4.34(\mathrm{~m}, 1 \mathrm{H}), 3.99$ (sept, $J=$ $6.2 \mathrm{~Hz}$ ), 3.78 (apparent t, $J=10.3 \mathrm{~Hz}, 1 \mathrm{H}), 3.65-3.71(\mathrm{~m}, 2 \mathrm{H}), 3.64$ and $3.60(\mathrm{AB}, J=14.0 \mathrm{~Hz}$, $2 \mathrm{H}), 3.39$ (apparent td, $J=5.1 \mathrm{~Hz}, J=9.3 \mathrm{~Hz}, 1 \mathrm{H}), 3.34$ (apparent t, $J=8.0 \mathrm{~Hz}, 1 \mathrm{H}), 1.26(\mathrm{~d}, J=$ $6.2 \mathrm{~Hz}, 3 \mathrm{H}), 1.21(\mathrm{~d}, J=6.2 \mathrm{~Hz}, 3 \mathrm{H}) ;{ }^{13} \mathrm{C} \mathrm{NMR}\left(75 \mathrm{MHz}, \mathrm{CDCl}_{3}\right): \delta 141.8,138.6,137.6,130.1$, 129.1, 128.9, 128.43, 128.37, 128.2, 127.7, 126.3, 126.2, 116.1, 102.6, 101.3, 81.7, 81.3, 81.1, 75.2, 74.0, 72.6, 69.0, 66.2, 37.3, 23.7, 22.2; ESIHRMS calcd for $\mathrm{C}_{33} \mathrm{H}_{42} \mathrm{NO}_{6} \mathrm{~S}\left[\mathrm{M}+\mathrm{NH}_{4}\right]^{+}$ 580.2733 ; found 580.2725 .

\subsection{Preparation of the glucosyl donor $\mathbf{2 8}$}

\subsubsection{Phenyl 2-O-Allyl-3-O-benzyl-4,6-O-benzylidene-1-thio- $\beta$-D-glucopyranoside (26)}

To a stirred solution of phenyl 3-O-benzyl-4,6- $O$-benzylidene-1-thio- $\beta$-D-glucopyranoside 25 $(1.37 \mathrm{~g}, 2.78 \mathrm{mmol})$ in distilled tetrahydrofuran $(15 \mathrm{~mL}), \mathrm{NaH}(363 \mathrm{mg}, 9.15 \mathrm{mmol}, 60 \%$ in oil) was added portionwise at room temperature under argon. The reaction mixture was stirred for 8 min and then allyl bromide $(1.15 \mathrm{~mL}, 9.62 \mathrm{mmol})$ was added. The reaction mixture was stirred at room temperature overnight. Methanol $(1 \mathrm{~mL})$ was added and then, the reaction mixture was concentrated under reduced pressure. The residue was re-dissolved in ethyl acetate, washed with sat. aq. $\mathrm{NaHCO}_{3}$ and then with brine, dried over $\mathrm{Na}_{2} \mathrm{SO}_{4}$, filtered and concentrated under reduced pressure. The solid pale yellow crude product (1.365 g, quant.) was used in the next step without further purification.

Mp 126- $127{ }^{\circ} \mathrm{C} ;[\alpha]_{\mathrm{D}}{ }^{25}-35\left(c=1, \mathrm{CHCl}_{3}\right) ; \mathrm{R}_{\mathrm{f}}=0.36($ EtOAc/Heptane, $20 / 80) ;{ }^{1} \mathrm{H}$ NMR $(500$ $\left.\mathrm{MHz}, \mathrm{CDCl}_{3}\right): \delta 7.27-7.54(\mathrm{~m}, 15 \mathrm{H}), 5.95-6.02(\mathrm{~m}, 1 \mathrm{H}), 5.57(\mathrm{~s}, 1 \mathrm{H}), 5.30$ and $5.19(\mathrm{ABX}, J=$ $1.5 \mathrm{~Hz}, J=17.2 \mathrm{~Hz}, J=10.4 \mathrm{~Hz}, 2 \mathrm{H}), 4.91$ and $4.79(\mathrm{AB}, J=11.3 \mathrm{~Hz}, 2 \mathrm{H}), 4.69(\mathrm{~d}, J=9.7 \mathrm{~Hz}$, $1 \mathrm{H}), 4.30-4.39(\mathrm{~m}, 3 \mathrm{H}), 3.75-3.81(\mathrm{~m}, 2 \mathrm{H}), 3.66$ (apparent t, $J=9.3 \mathrm{~Hz}, 1 \mathrm{H}), 3.46$ (apparent td, $J$ $=5.1 \mathrm{~Hz}, J=9.8 \mathrm{~Hz}, 1 \mathrm{H}), 3.38(\mathrm{dd}, J=9.7 \mathrm{~Hz}, 1 \mathrm{H}) ;{ }^{13} \mathrm{C} \mathrm{NMR}\left(125 \mathrm{MHz}, \mathrm{CDCl}_{3}\right): \delta 138.5$, $137.4,134.9,133.3,132.4,129.1,128.5,128.4,128.3,128.0,127.9,126.2,117.4,101.3,88.4$, 
83.0, 81.5, 80.4, 75.4, 74.8, 70.4, 68.9; ESIHRMS calcd for $\mathrm{C}_{29} \mathrm{H}_{34} \mathrm{NO}_{5} \mathrm{~S}\left[\mathrm{M}+\mathrm{NH}_{4}\right]^{+}$508.2158; found 508.2145 .

\subsubsection{Phenyl 3-O-Benzyl-4,6-O-benzylidene-2-O-(3-hydroxypropyl)-1-thio- $\beta$-D-glucopyranoside} (27)

To a stirred solution of compound 26 (1.3655 g, $2.78 \mathrm{mmol})$ in anhydrous tetrahydrofuran (15 $\mathrm{mL}$ ), was added 9-BBN (715 mg, $2.93 \mathrm{mmol}$ ) at room temperature, under argon. The mixture was stirred for $5 \mathrm{~h}$. Water $(1 \mathrm{~mL})$ was then added at $0{ }^{\circ} \mathrm{C}$ to destroy the excess of 9-BBN. Then, $\mathrm{NaOH}(0.93 \mathrm{~mL}, 2.78 \mathrm{mmol}, 3 \mathrm{M})$ and $\mathrm{H}_{2} \mathrm{O}_{2}(0.9 \mathrm{~mL}, 8.91 \mathrm{mmol}, 30 \%)$ were successively added. The reaction mixture turned into a white suspension that was stirred overnight at room temperature, and then concentrated in vacuo. The oily crude product was purified by flash chromatography (with a pre-column) on a pre-packed silica column (40 g, $50 \mu \mathrm{m}$, EtOAc/Heptane: 5/95 30/70), to give compound $27(15.7 \mathrm{mg}, 72 \%)$ as a pale yellow oil. Mp $145-146{ }^{\circ} \mathrm{C} ;[\alpha]_{\mathrm{D}}{ }^{25}-40\left(c=1, \mathrm{CHCl}_{3}\right) ; R_{\mathrm{f}}=0.54\left(\right.$ EtOAc/Heptane, 50/50); ${ }^{1} \mathrm{H}$ NMR $(500$ $\left.\mathrm{MHz}, \mathrm{CDCl}_{3}\right): \delta$ 7.30-7.54 (m, 15H), $5.57(\mathrm{~s}, 1 \mathrm{H}), 4.94$ and $4.77(\mathrm{AB}, J=11.2 \mathrm{~Hz}, 2 \mathrm{H}), 4.65(\mathrm{~d}$, $J=9.8 \mathrm{~Hz}, 1 \mathrm{H}$ ), 4.37 (dd, $J=5.0 \mathrm{~Hz}, J=8.5 \mathrm{~Hz}, 1 \mathrm{H}), 3.99-4.03(\mathrm{~m}, 1 \mathrm{H}), 3.91$ (apparent td, $J=$ $4.3 \mathrm{~Hz}, J=9.7 \mathrm{~Hz}, 1 \mathrm{H}), 3.73-3.81(\mathrm{~m}, 4 \mathrm{H}), 3.67$ (apparent t, $J=9.3 \mathrm{~Hz}, 1 \mathrm{H}$ ), 3.45 (apparent td, $J$ $=5.0 \mathrm{~Hz}, J=9.7 \mathrm{~Hz}, 1 \mathrm{H}), 3.30(\mathrm{dd}, J=8.5 \mathrm{~Hz}, 1 \mathrm{H}), 2.23(\mathrm{t}, J=6.1 \mathrm{~Hz}, 1 \mathrm{H}), 1.78-1.89(\mathrm{~m}, 2 \mathrm{H})$;

${ }^{13} \mathrm{C}$ NMR $\left(125 \mathrm{MHz}, \mathrm{CDCl}_{3}\right)$ : $\delta 138.4,137.4,132.9,132.6,129.23,129.16,128.6,128.4,128.2$, 128.0, 126.1, 101.3, 88.5, 82.9, 81.6, 80.8, 75.3, 72.4, 70.4, 68.8, 61.2, 32.7; ESIHRMS calcd for $\mathrm{C}_{29} \mathrm{H}_{36} \mathrm{NO}_{6} \mathrm{~S}\left[\mathrm{M}+\mathrm{NH}_{4}\right]^{+}$526.2263; found 526.2265.

\subsubsection{Phenyl 3-O-Benzyl-4,6-O-benzylidene-2-O-(3-hydroxypropyl)- $\beta$-D-glucopyranosyl sulfoxide (28)}

To a stirred solution of thioglycoside $27(500 \mathrm{mg}, 0.98 \mathrm{mmol})$ in dichloromethane $(24 \mathrm{~mL})$, at $78^{\circ} \mathrm{C}$ meta-chloroperbenzoic acid (223 $\mathrm{mg}, 0.99 \mathrm{mmol}, 77 \%$ ) was added under argon. The reaction mixture was stirred for $1 \mathrm{~h}$ at $-78^{\circ} \mathrm{C}$ and then progressively warmed to $-36{ }^{\circ} \mathrm{C}$ over $1 \mathrm{~h}$ when aq. $\mathrm{NaHCO}_{3}$ sat. $(2 \mathrm{~mL})$ was added. The mixture was extracted twice with dichloromethane. The combined organic phases were washed with aq. sat. $\mathrm{NaHCO}_{3}$, with brine, dried over $\mathrm{Na}_{2} \mathrm{SO}_{4}$, filtered, and the organic layer was evaporated under reduced pressure. The crude product was purified by flash chromatography on a pre-packed silica column ( $40 \mathrm{~g}, 50 \mu \mathrm{m}$, 
EtOAc/Heptane: 10/90 to 50/50) to give the glucosyl sulfoxides $\left(\boldsymbol{S}_{\mathbf{R}}\right)-\mathbf{2 8}(297 \mathrm{mg}, \mathbf{5 7 \%}$, white solid) and $\left(\boldsymbol{S}_{\mathrm{S}}\right)-\mathbf{2 8}(154 \mathrm{mg}, 28 \%$, white solid $)$.

$\left(S_{\mathbf{R}}\right)-28 \mathrm{Mp} 143{ }^{\circ} \mathrm{C} ;[\alpha]_{\mathrm{D}}{ }^{25}-155\left(c=1, \mathrm{CHCl}_{3}\right) ; R_{\mathrm{f}}=0.08\left(\right.$ EtOAc/Heptane, 50/50); ${ }^{1} \mathrm{H}$ NMR (500 MHz, $\left.\mathrm{CDCl}_{3}\right): \delta 7.32-7.62(\mathrm{~m}, 15 \mathrm{H}), 5.50(\mathrm{~s}, 1 \mathrm{H}), 4.97$ and $4.79(\mathrm{AB}, J=11.5 \mathrm{~Hz}, 2 \mathrm{H})$, 4.16-4.20 (m, 1H), 3.99-4.07 (m, 2H), $4.00(\mathrm{~d}, J=9.4 \mathrm{~Hz}, 1 \mathrm{H}), 3.90$ (apparent t, $J=9.1 \mathrm{~Hz}, 1 \mathrm{H}$ ), 3.84-3.69 (m, 5H, H-3), 3.29 (dd, $J=5.0 \mathrm{~Hz}, J=9.8 \mathrm{~Hz}, 1 \mathrm{H}), 2.18$ (t, $J=5.6 \mathrm{~Hz}, 1 \mathrm{H}), 1.85-1.90$ (m, 2H); ${ }^{13} \mathrm{C}$ NMR $\left(125 \mathrm{MHz}, \mathrm{CDCl}_{3}\right): \delta 139.1,138.3,137.1,131.4,129.2,129.1,128.6,128.4$, $128.1,128.0,126.1,125.4,101.4,93.5,82.6,81.3,76.8,75.0,72.2,71.2,68.2,60.7,33.0$; ESIHRMS calcd for $\mathrm{C}_{29} \mathrm{H}_{33} \mathrm{O}_{7} \mathrm{~S}[\mathrm{M}+\mathrm{H}]^{+}$525.1947; found 525.1948.

$\left(S_{\mathrm{S}}\right)-28:(145 \mathrm{mg}, 28 \%) ; \mathrm{Mp} 138{ }^{\circ} \mathrm{C} ;[\alpha]_{\mathrm{D}}{ }^{25}+5\left(c=1, \mathrm{CHCl}_{3}\right) ; R_{\mathrm{f}}=0.14($ EtOAc/Heptane, 50/50); ${ }^{1} \mathrm{H}$ NMR (500 MHz, $\left.\mathrm{CDCl}_{3}\right): \delta 7.30-7.68(\mathrm{~m}, 15 \mathrm{H}), 5.53(\mathrm{~s}, 1 \mathrm{H}), 4.93$ and $4.74(\mathrm{AB}, J=$ 11.2 Hz, 2H), 4.34 (d, $J=8.6 \mathrm{~Hz}, 1 \mathrm{H}), 4.30(\mathrm{dd}, J=4.9 \mathrm{~Hz}, J=10.7 \mathrm{~Hz}, 1 \mathrm{H}), 3.99-4.03(\mathrm{~m}, 1 \mathrm{H})$, 3.77-3.89 (m, 3H), 3.57-3.70 (m, 3H), 3.46 (apparent td, $J=4.9 \mathrm{~Hz}, J=10.0 \mathrm{~Hz}, 1 \mathrm{H}), 2.62(\mathrm{t}, J=$ $6.0 \mathrm{~Hz}, 1 \mathrm{H}), 1.61-1.68(\mathrm{~m}, 2 \mathrm{H}) ;{ }^{13} \mathrm{C} \mathrm{NMR}\left(125 \mathrm{MHz}, \mathrm{CDCl}_{3}\right): \delta 140.7,138.2,137.1,131.6$, 129.2, 129.1, 128.6, 128.4, 128.2, 128.0, 126.1, 125.4, 101.4, 95.1, 83.0, 81.1, 77.4, 75.2, 70.37, 70.34, 68.4, 60.0, 32.7; ESIHRMS calcd for $\mathrm{C}_{29} \mathrm{H}_{33} \mathrm{O}_{7} \mathrm{~S}[\mathrm{M}+\mathrm{H}]^{+}$525.1947; found 525.1948.

\subsection{Cyclization of Glucosyl Sulfoxide $\mathbf{2 8}$}

Sulfoxide 28 (0.052 g, $0.099 \mathrm{mmol})$ and anhydrous TTBP $(0.1525 \mathrm{~g}, 0.614 \mathrm{mmol})$ were dissolved in freshly distilled dichloromethane $(6 \mathrm{~mL})$ under argon. 1 -Octene $(0.16 \mathrm{~mL}, 1.02 \mathrm{mmol})$ and triflic anhydride $(25 \mu \mathrm{L})$ were then added at $-72^{\circ} \mathrm{C}$. The reaction mixture was stirred at $-72^{\circ} \mathrm{C}$ for a further $2.5 \mathrm{~h}$ and then saturated aqueous $\mathrm{NaHCO}_{3}$ was added to quench the reaction at that temperature. The mixture was stirred again at room temperature for additional $1 \mathrm{~h}$. It was diluted with dichloromethane, washed with saturated aqueous $\mathrm{NaHCO}_{3}$ and with brine, dried over $\mathrm{Na}_{2} \mathrm{SO}_{4}$, filtered, concentrated under reduced pressure. The white solid crude product was as purified by flash chromatography on a pre-packed silica column (12 g, $50 \mu \mathrm{m}$, AcOEt/Heptane: 1/99 50/50 containing $1 \% \mathrm{Et}_{3} \mathrm{~N}$ ), to give compound 29 as a white solid (15 $\mathrm{mg}, 38 \%$ )

\subsubsection{3-O-Benzyl-4,6-O-benzylidene-1,2-O-(1,3-propanediyl)- $\beta$-D-glucopyranose (29)} $\operatorname{Mp} 147-158{ }^{\circ} \mathrm{C} ;[\alpha]_{\mathrm{D}}{ }^{25}-35\left(c=1, \mathrm{CHCl}_{3}\right) ; R_{\mathrm{f}}=0.32\left(\right.$ EtOAc/Heptane, 50/50); ${ }^{1} \mathrm{H}$ NMR $(500$ $\left.\mathrm{MHz}_{\mathrm{CDCl}}\right): \delta$ 7.28-7.49 (m, 10H), $5.56(\mathrm{~s}, 1 \mathrm{H}), 4.89$ and $4.85(\mathrm{AB}, J=11.7 \mathrm{~Hz}, 2 \mathrm{H}), 4.57$ (d, 
$J=7.9 \mathrm{~Hz}, 1 \mathrm{H}), 4.37(\mathrm{dd}, J=4.8 \mathrm{~Hz}, J=10.4 \mathrm{~Hz}, 1 \mathrm{H}), 4.11-4.16(\mathrm{~m}, 2 \mathrm{H}), 3.91-3.95(\mathrm{~m}, 1 \mathrm{H})$, 3.75-3.81 (m, 2H), 3.63-3.70 (m, 2H), 3.45-3.50 (m, 2H), 2.05-2.13 (m, 1H), 1.93-2.00 (m, 1H); ${ }^{13} \mathrm{C} \mathrm{NMR}\left(125 \mathrm{MHz}, \mathrm{CDCl}_{3}\right): \delta 138.8,137.4,129.1,128.40,128.37,127.9,127.7,126.2,103.9$, 101.5, 83.9, 81.4, 79.8, 75.1, 69.6, 68.9, 67.5, 64.8, 32.3; ESIHRMS calcd for $\mathrm{C}_{23} \mathrm{H}_{26} \mathrm{O}_{6} \mathrm{Na}[\mathrm{M}+$ $\mathrm{Na}]^{+} 421.1627$; found 421.1633 .

\subsection{Competitive glycosylation using donor 28}

Freshly activated molecular sieves (ca. $150 \mathrm{mg}, 4 \AA$, powdered) and distilled 1-octene ( $0.1 \mathrm{~mL}$, $0.637 \mathrm{mmol}$ ) were added to a solution of sulfoxide $28(31.3 \mathrm{mg}, 0.06 \mathrm{mmol})$ and anhydrous TTBP (63 mg, $0.254 \mathrm{mmol}$ ) in freshly distilled dichloromethane under argon. The mixture was vigorously stirred and then cooled to $-72{ }^{\circ} \mathrm{C}$ before freshly distilled triflic anhydride $(16 \mu \mathrm{L}$, $0.095 \mathrm{mmol})$ was added in one portion. Freshly distilled isopropanol $(14 \mu \mathrm{L}, 0.182 \mathrm{mmol})$ was then added. The reaction mixture was stirred for a further $2.5 \mathrm{~h}$ and saturated aqueous $\mathrm{NaHCO}_{3}$ $(1 \mathrm{~mL})$ was added to quench the reaction at $-72{ }^{\circ} \mathrm{C}$. The mixture was stirred again for a further 1 $\mathrm{h}$ at this temperature, and then warmed to room temperature. It was diluted with dichloromethane, and washed with saturated aqueous $\mathrm{NaHCO}_{3}$ and with brine, dried over $\mathrm{Na}_{2} \mathrm{SO}_{4}$, filtered, and concentrated under reduced pressure. The residue was purified by flash chromatography on a prepacked silica column ( $4 \mathrm{~g}, 50 \mu \mathrm{m}$, EtOAc/Heptane: 1/99 50/50), to give the glucosylation products $\mathbf{3 0 \alpha}(2.7 \mathrm{mg}, 10 \%)$ and $\mathbf{3 0 \beta}(4.7 \mathrm{mg}, 15 \%)$.

\subsubsection{Isopropyl 3-O-Benzyl-4,6-O-benzylidene-2-O-(3-hydroxypropyl)- $\alpha$-D-glucopyranoside $(30 \alpha)$}

$\mathrm{Mp} 82{ }^{\circ} \mathrm{C} ;[\alpha]_{\mathrm{D}}{ }^{25}+20\left(c=1, \mathrm{CHCl}_{3}\right) ; R_{f}=0.29(\mathrm{AcOEt} / \mathrm{Heptane}, 20 / 80) ;{ }^{1} \mathrm{H} \mathrm{NMR}(500 \mathrm{MHz}$, $\left.\mathrm{CDCl}_{3}\right): \delta$ 7.28-7.50 (m, 10H), $5.57(\mathrm{~s}, 1 \mathrm{H}), 5.07(\mathrm{~d}, J=3.8 \mathrm{~Hz}, 1 \mathrm{H}), 4.91$ and $4.79(\mathrm{AB}, J=11.3$ $\mathrm{Hz}, 2 \mathrm{H}), 4.27(\mathrm{dd}, J=4.9 \mathrm{~Hz}, J=10.1 \mathrm{~Hz}, 1 \mathrm{H}), 3.97$ (apparent t, $J=9.3 \mathrm{~Hz}, 1 \mathrm{H}), 3.89-3.94(\mathrm{~m}$, 2H), 3.77-3.81 (m, 4H), 3.72 (apparent t, $J=10.3 \mathrm{~Hz}, 1 \mathrm{H}$ ), 3.62 (apparent t, $J=9.3 \mathrm{~Hz}, 1 \mathrm{H}$ ), 3.45 $(\mathrm{dd}, J=3.8 \mathrm{~Hz}, J=9.3 \mathrm{~Hz}, 1 \mathrm{H}), 1.77-1.92(\mathrm{~m}, 2 \mathrm{H}), 1.26(\mathrm{~d}, J=6.1 \mathrm{~Hz}, 3 \mathrm{H}), 1.22(\mathrm{~d}, J=6.1 \mathrm{~Hz}$, $3 \mathrm{H}) ;{ }^{13} \mathrm{C}$ NMR $\left(125 \mathrm{MHz}, \mathrm{CDCl}_{3}\right): \delta 138.9,137.6,129.1,128.5,128.4,128.1,127.7,126.2$, 101.4, 95.7, 82.6, 80.4, 78.5, 75.3, 71.2, 70.3, 69.2, 62.6, 62.3, 32.3, 23.5, 21.4; ESIHRMS calcd for $\mathrm{C}_{26} \mathrm{H}_{34} \mathrm{O}_{7} \mathrm{Na}[\mathrm{M}+\mathrm{Na}]^{+}$481.2202; found: 481.2215. 
4.10.2. Isopropyl 3-O-Benzyl-4,6-O-benzylidene-2-O-(3-hydroxypropyl)- $\beta$-D-glucopyranoside $(30 \beta)$

$\mathrm{Mp} 89^{\circ} \mathrm{C} ;[\alpha]_{\mathrm{D}}{ }^{25}-45\left(c=1, \mathrm{CHCl}_{3}\right) ; R_{\mathrm{f}}=0.49($ EtOAc/Heptane, $50 / 50) ;{ }^{1} \mathrm{H}$ NMR $(500 \mathrm{MHz}$, $\left.\mathrm{CDCl}_{3}\right): \delta$ 7.29-7.49 (m, 10H), $5.55(\mathrm{~s}, 1 \mathrm{H}), 4.93$ and $4.77(\mathrm{AB}, J=11.2 \mathrm{~Hz}, 2 \mathrm{H}), 4.48(\mathrm{~d}, J=7.7$

$\mathrm{Hz}, 1 \mathrm{H}), 4.32(\mathrm{dd}, J=5.0 \mathrm{~Hz}, J=10.5 \mathrm{~Hz}, 1 \mathrm{H}), 3.99-4.03(\mathrm{~m}, 2 \mathrm{H}), 3.89-3.93(\mathrm{~m}, 1 \mathrm{H}), 3.74-3.81$ (m, 3H), 3.64-3.67 (m, 2H), 3.36-3.41 (m, 1H), 3.22-3.25 (m, 1H), $2.25(\mathrm{t}, J=5.3 \mathrm{~Hz}, 1 \mathrm{H}), 1.76-$ $1.86(\mathrm{~m}, 2 \mathrm{H}), 1.26(\mathrm{~d}, J=6.2 \mathrm{~Hz}, 3 \mathrm{H}), 1.23(\mathrm{~d}, J=6.2 \mathrm{~Hz}, 3 \mathrm{H}) ;{ }^{13} \mathrm{C} \mathrm{NMR}\left(125 \mathrm{MHz}, \mathrm{CDCl}_{3}\right): \delta$ 138.6, 137.5, 129.1, 128.5, 128.4, 128.2, 127.8, 126.2, 102.2, 101.3, 82.7, 81.8, 81.1, 75.1, 72.7, 72.5, 69.0, 66.2, 61.7, 32.6, 23.7, 21.9; ESIHRMS calcd for $\mathrm{C}_{26} \mathrm{H}_{34} \mathrm{O}_{7} \mathrm{Na}[\mathrm{M}+\mathrm{Na}]^{+} 481.2202$; found 481.2222 .

Acknowledgement. We thank the NIH (GM62160) and the ICSN for financial support, and the NSF for funds in support of the $600 \mathrm{MHz}$ spectrometer in the Lumigen Instrument Center at WSU (MRI-084043). M.H. is grateful to the Ministère de l'Education Nationale, de la Recherche, et de la Technologie, France for fellowship support.

\section{References}

(1) Huang, M.; Retailleau, P.; Bohé, L.; Crich, D. J. Am. Chem. Soc. 2012, 134, 14746-14749.

(2) Adero, P. O.; Furukawa, T.; Huang, M.; Mukherjee, D.; Retailleau, P.; Bohé, L.; Crich, D. J. Am. Chem. Soc. 2015, 137, 10336-10345.

(3) Bohé, L; Crich, D. C. R. Chim. 2011, 14, 3-16.

(4) Bohé, L; Crich, D. Carbohydr. Res. 2015, 403, 48-59.

(5) Schinzer, D. Synthesis 1988, 263-273.

(6) Kahne, D.; Walker, S.; Cheng, Y.; Van Engen, D. 1989, 111, 6881-6882.

(7) Crich, D.; Lim, L. B. L. Org. React. 2004, 64, 115-251.

(8) Eliel, E.L.; Wilen, S. H. Stereochemistry of Organic Compounds Wiley-Interscience NY 1994.

(9) Christensen, H. M., Oscarson S.; Jensen, H. H. Carbohydr. Res. 2015, 408, 51-95.

(10) Gildersleeve, J.; Smith, A.; Sakurai, D. Raghavan, S.; Kahne, D. J. Am. Chem. Soc. 1999, $121,6176-6182$.

(11) Crich, D.; Wu, B. Org. Lett. 2006, 8, 4879-4882. 
(12) Gu, X.; Chen, L.; Wang, X.; Liu, X.; You, Q.; Xi, W.; Cao, L.; Chen, G.; Chen, Y.-L.; Xiong, B.; Shen, J. J. Org. Chem. 2014, 79, 1100-1110.

(13) Pouilly, P. de; Chenede, A.; Mallet, J.-M.; Sinaÿ, P., Bull. Soc. Chim. Fr. 1993, 130, 256265.

(14) Lu, L.; Zhang, W.; Nam, S.; Horne, D. A.; Jove, R.; Carter, R. G. J. Org. Chem. 2013, 78, 2213-2247.

(15) Kim, J. H.; Yang, H.; Park. J.; Boons, G. J. J. Am. Chem. Soc. 2005, 127, 12090-12097.

(16) Fascione, M. A.; Kilner, C. A.; Leach, A. G.; Turnbull, W. B. Chem. Eur. J. 2012, 18, 321333.

(17) Cox, D. J.; Fairbanks, A. J. Tetrahedron Asymmetry 2009, 20, 773-780.

(18) Fascione, M. A.; Adshead, S. J.; Mandal, P. K.; Kilner, C. A.; Leach, A. G.; Turnbull, W. B. Chem. Eur. J. 2012, 18, 2987-2997.

(19) Beaver, M. G.; Billings, S. B.; Woerpel, K. A. J. Am. Chem. Soc. 2008, 130, 2082-2086.

(20) Cox, D. J.; Singh, G. P.; Watson, A. J. A.; Fairbanks, A. J. Eur. J. Org. Chem. 2014, 46244642.

(21) Fraser-Reid, B.; Wu, Z. C.; Andrews, W.; Skowronski, E. J. Am. Chem. Soc. 1991, 113, $1434-1435$.

(22) Andrews, C. W.; Rodebaugh, R.; Fraser-Reid, B. J. Org. Chem. 1996, 61, 5280-5289.

(23) Jensen, H. H.; Nordstrom, M.; Bols, M. J. Am. Chem. Soc. 2004, 126, 9205-9213.

(24) Pedretti, V.; Veyrieres, A.; Sinaÿ, P. Tetrahedron 1990, 46, 77-88.

(25) Liang, H.; MacKay, M.; Grindley, T. B.; Robertson, K. N.; Cameron, T. S. Can. J. Chem. 2010, $88,1154-1174$

(26) Moya-López, J. F.; Elhalem, E.; Recio, R.; Álvarez, E.; Fernández, I.; Khiar, N. Org. Biomol. Chem. 2015, 13, 1904-1914.

(27) Bock, K.; Pedersen, C. J. Chem. Soc., Perkin Trans. 2, 1974, $293-297$.

(28) Crich, D.; Cai, W. J. Org. Chem. 1999, 64, 4926-4930.

(29) Bousquet, E.; Khitri, M.; Lay, L.; Nicotra, F.; Panza, L.; Russo, G. Carbohydr. Res. 1998, $311,171-181$.

(30) Lourenço, E. C.; Maycock, C. D.; Ventura, M. R. Carbohydr. Res. 2009, 344, 2073-2078. (31) Huang, M.; Garrett, G. E.; Birlirakis, N.; Bohé, L.; Pratt, D. A.; Crich, D. Nature Chem. 2012, 4, 663-667. 

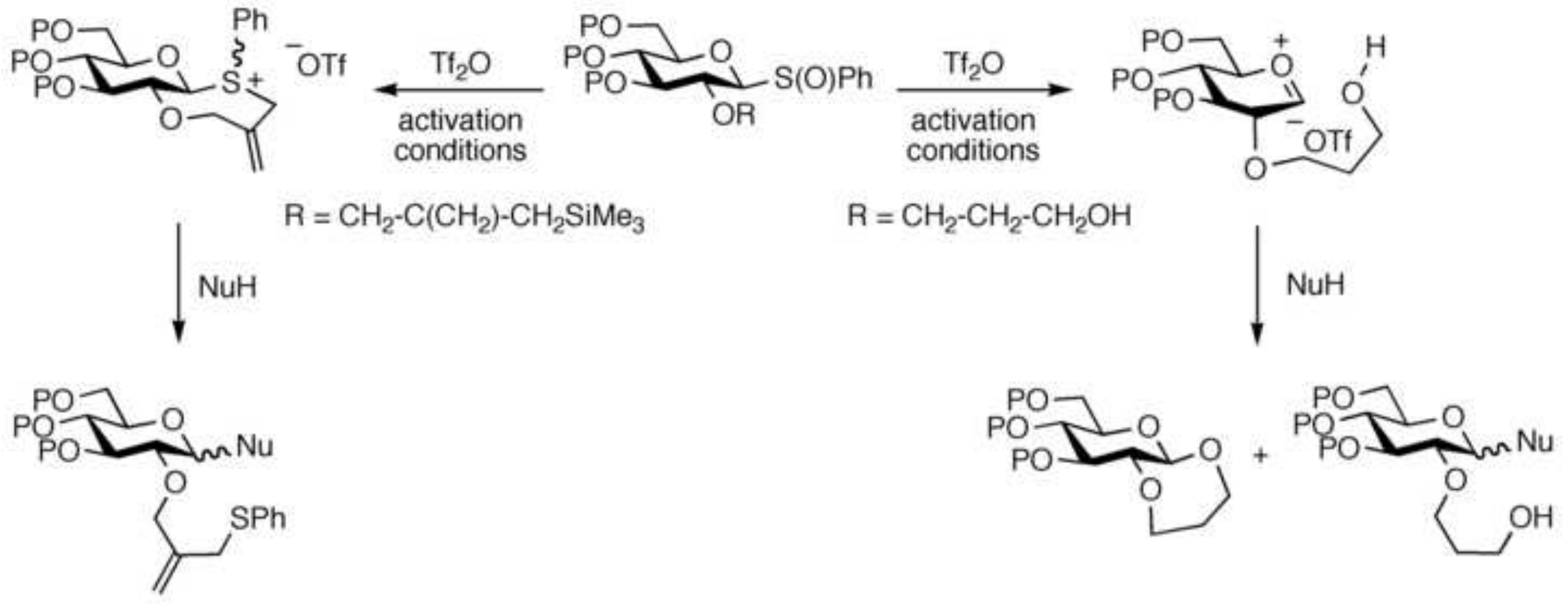